\title{
Compositional Evolution of the Variscan Intra-Orogenic Extensional Magmatism in the Valencia del Ventoso Plutonic Complex, Ossa-Morena Zone (SW Iberia): A View from Amphibole Compositional Relationships
}

\author{
Aitor Cambeses $^{1}\left(\mathbb{D}\right.$, José F. Molina ${ }^{1, * \mathbb{D}}$, Irene Morales ${ }^{1} \mathbb{D}$, Concepción Lázaro ${ }^{1}$, Juan A. Moreno ${ }^{2} \mathbb{D}$, \\ Pilar Montero ${ }^{1}$ and Fernando Bea ${ }^{1}$ D \\ 1 Departamento de Mineralogía y Petrología, Universidad de Granada, Campus de Fuentenueva, \\ 18002 Granada, Spain; aitorc@ugr.es (A.C.); iremoral@ugr.es (I.M.); clazaro@ugr.es (C.L.); \\ pmontero@ugr.es (P.M.); fbea@ugr.es (F.B.) \\ 2 Consejo Nacional de Investigaciones Científicas y Tecnológicas (CONICET), Centro de Investigaciones en \\ Ciencias de la Tierra (CICTERRA), Universidad Nacional de Córdoba (UNC), Córdoba X5016CGA, Argentina; \\ jmoreno_2@ugr.es \\ * Correspondence: jfmolina@ugr.es
}

Citation: Cambeses, A.; Molina, J.F.; Morales, I.; Lázaro, C.; Moreno, J.A.; Montero, P.; Bea, F. Compositional Evolution of the Variscan Intra-Orogenic Extensional Magmatism in the Valencia del Ventoso Plutonic Complex, Ossa-Morena Zone (SW Iberia): A View from Amphibole Compositional Relationships. Minerals 2021, 11, 431. https://doi.org/10.3390/min11040431

Academic Editor: Alain Chauvet

Received: 6 March 2021

Accepted: 15 April 2021

Published: 18 April 2021

Publisher's Note: MDPI stays neutral with regard to jurisdictional claims in published maps and institutional affiliations.

Copyright: (C) 2021 by the authors. Licensee MDPI, Basel, Switzerland. This article is an open access article distributed under the terms and conditions of the Creative Commons Attribution (CC BY) license (https:// creativecommons.org/licenses/by/ $4.0 /)$.

\begin{abstract}
The Ossa-Morena Zone (OMZ), SW Iberia, has numerous Lower Carboniferous compositionally zoned plutons that formed in a Variscan intra-orogenic extensional setting. This magmatism shows a wide compositional variation comprising alkaline, transitional, and calc-alkaline suites. The calc-alkaline suite was produced by hybridization of alkaline magmas with felsic melts generated by crustal anatexis related to the intrusion of mafic magmas in the middle crust. In this work, we present a textural and mineralogical study of the Variscan Valencia del Ventoso main pluton from the OMZ to track the compositional evolution of magmas during hybridization using constraints from amphibole compositions and to determine the $P$ - $T$ conditions of emplacement using amphibolebased thermobarometry. This pluton exhibits reverse zoning with an inner facies containing alkaline dolerites, gabbros, and quartz diorites, an intermediate facies with transitional diorites, and an outer facies with calc-alkaline quartz diorites to monzogranites. Magmas from the intermediate and border facies crystallized under oxidizing conditions at relatively low temperatures (range: $640-760{ }^{\circ} \mathrm{C}$ ) and ca. 280-300 MPa, implying near $\mathrm{H}_{2} \mathrm{O}$-saturated conditions. These rock facies show mineralogical evidence of hybridization between alkaline to mildly alkalic and calc-alkaline magmas. The former is inferred from the occurrence of antecrysts of labradorite-andesine, high-Ti pargasite-hastingsite, and biotite with deficiency in tetrahedral-site occupancy, a distinctive feature of biotite from the inner facies alkaline dolerites. This contrasts with later crystallization from the calc-alkaline magma of andesine-oligoclase, low-Ti magnesiohornblende-edenite, and biotite with full tetrahedral-site occupancy. Constraints from amphibole-melt compositional relationships in antecrystic high-Ti amphibole suggest that the alkaline magmatic component could have a high- to ultra-K affinity.
\end{abstract}

Keywords: amphibole compositional relationships; amphibole-plagioclase thermobarometry; postcollisional magmatism; magma mixing and hybridization; Ossa-Morena Zone; Iberia; Variscan orogen

\section{Introduction}

An assessment of the contribution of the mantle in the magmatism of continental petrogenetic settings is important to understanding the dynamics of crust-mantle interactions and the mechanisms of crustal growth. In collisional orogens, this is a difficult task because mantle-derived magmas must cross a thickened hot continental crust that experiences anatexis and devolatilization generating melts and fluids that can modify their composition significantly as discussed in Bea et al. [1]. 
However, the composition of phenocrysts (crystallized directly from the magma), xenocrysts (extraneous to the whole magma plumbing system), and antecrysts (recycled in their own active magma plumbing system by various events) can provide valuable constraints on the nature of the components involved in hybrid magmas (e.g., [2-9]). Amphibole is very useful for this purpose because it can record the compositional changes in host magma from early to late crystallization stages. Molina et al. [2] showed that the $\mathrm{TiO}_{2}$ content of magmatic amphibole is sensitive to the alkalinity of the liquid from which it crystallized. These authors also derived expressions based on the relationships between melt silica content and amphibole-melt $\mathrm{K}_{2} \mathrm{O}$ and $\mathrm{Na}_{2} \mathrm{O}-\mathrm{K}_{2} \mathrm{O}$ partitioning that allow an estimation of alkali contents as a function of silica in amphibole-saturated melts (see also $[3-5,10])$.

The Ossa-Morena Zone (OMZ), SW Iberia, was intruded by numerous compositionally zoned plutons that formed in a Variscan intra-orogenic extensional setting during the Lower Carboniferous [3-5,11-14]. They show textural and compositional evidence for hybridization that caused a calc-alkaline compositional trend. However, compositional relationships in amphibole phenocrysts from one of these intrusions, the Brovales pluton, revealed the involvement of an alkaline mantle-derived component [5].

In this work, we present a mineralogical study of the Valencia del Ventoso pluton, which has large compositional variability, including dolerites and diorites to monzogranites [3,4]. Amphibole compositions are used to track the compositional evolution of magmas during hybridization. We also determine the $P-T$ conditions at which the hybridization took place using the amphibole-plagioclase barometer from Molina et al. [15], the amphiboleplagioclase thermometer from Molina et al. [16], and the Al-in-hornblende barometer from Mutch et al. [17].

\section{Geological Setting}

The OMZ is a Gondwana continental block, located in the westernmost end of the European Variscan Belt, between the Central Iberian Zone (CIZ) to the north, and the South Portuguese Zone (SPZ) to the south. It comprises an Ediacaran to early Carboniferous continuous stratigraphic succession (Figure 1A,B) affected by the Cadomian, late Neoproterozoic, and Variscan, Early Carboniferous, orogenies, and by the Cambro-Ordovician extension (see Cambeses et al. $[4,18]$ and references therein).

The following sequence of deformation phases has been recognized in the OMZ during the Variscan orogeny (e.g., [19-30]): D1 initial collision (ca. 345-390 Ma) generating recumbent, km-scale, NW-SE-oriented SW-vergent folds (e.g., Olivenza-Monesterio antiform), and SW-directed thrusts (e.g., Monesterio thrust); D2 intra-orogenic extension/transtension (ca. 330-345 Ma) producing shear zones and sedimentary basin subsidence; and D3 final collision (ca. 305-330 Ma) causing upright folding and thrusting as well as strike-slip faulting.

Conspicuous magmatism is associated to the two orogenies and the Cambro-Ordovician extension $[11,31]$. The Variscan magmatism, volumetrically more important, took place, along with HT-LP metamorphism (700-900 ${ }^{\circ} \mathrm{C}$ and 300-500 MPa) and crustal anatexis, during the extensional/transtensional D2 phase at ca. 350-330 Ma (Early Carboniferous) (e.g., [3-5,14,32-34]). This magmatism is represented by calc-alkaline metaluminous zoned plutons that range mostly from gabbros and diorites to granodiorites with minor peraluminous granites. It is especially well-exposed in the core of the Olivenza-Monesterio antiform that is intruded by the Burguillos del Cerro, Valencia del Ventoso, and Brovales plutons, thus post-dating the D1 compressional phase (Figure 1C). Deeper mafic-ultramafic Variscan intrusions have been inferred from the existence of a mid-crustal highly reflective layer, the IBERSEIS Reflective Body (IRB), detected in a deep-seismic reflection profile across the northern SPZ, OMZ, and southern CIZ (Figure 1A) [29,35-37]. 

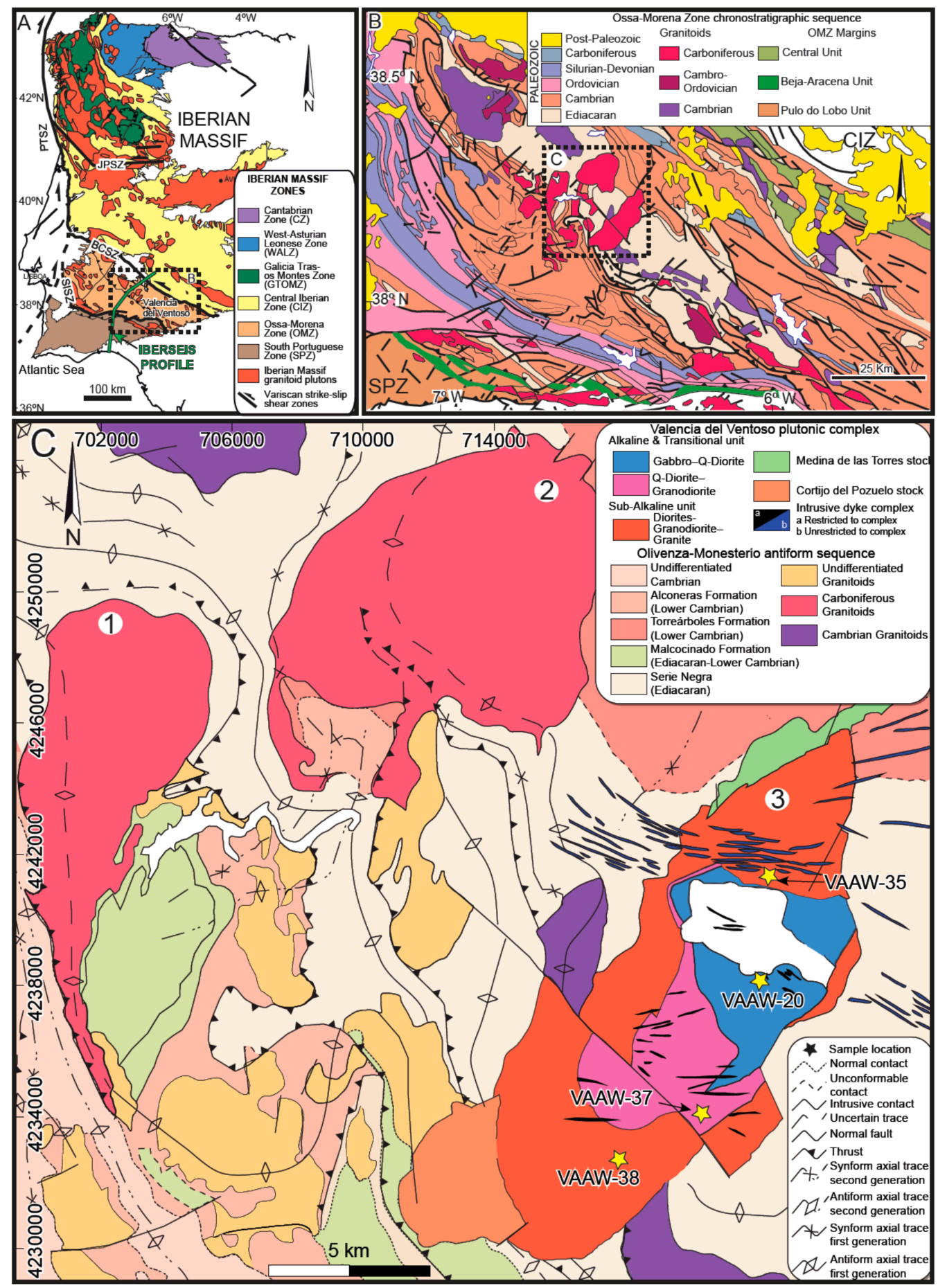

Figure 1. (A) Zones of the Iberian Massif indicating the distribution of granitoids as indicated in [38]; (B) chronostratigraphic sequence of the Ossa-Morena Zone (OMZ) showing the different stages of magmatism and highlighting the Pulo do Lobo Unit and the OMZ boundaries with the Central Iberian Zone and the South Portuguese Zone, modified from [39]; (C) schematic geological map of the Olivenza-Monesterio antiform, modified from [40]. 1: Brovales pluton, 2: Burguillos del Cerro pluton, and 3: Valencia del Ventoso plutonic complex showing the distribution of the main facies, adapted from $[4,41]$. Stars indicate the location of representative samples of each facies. This figure was published in [4], and it has copyright permission from the International Association for Gondwana Research to be modified and used in the present work. 


\section{The Valencia del Ventoso Plutonic Complex}

The Valencia del Ventoso plutonic complex is exposed over an area of $150 \mathrm{~km}^{2}$ in the central part of the Olivenza-Monesterio antiform (Figure 1C) where intruded Ediacaran and Lower Cambrian sedimentary formations cutting also the contacts of Cambrian granitoids (Figure 1C, see also [4,42]). Its shape is elliptical in map view with the long axis in the northeast to southwest direction.

The Valencia del Ventoso plutonic complex contains three intrusive bodies [4,40,41,43-46]: the Valencia del Ventoso main pluton (VVP), the Medina de las Torres stock (MTS) in the north, and the Cortijo del Pozuelo stock (CPS) in the south (Figure 1C). The plutons are cut by dike swarms of variable compositions (dolerites to microsyenites and aplites to pegmatites).

The VVP displays a reverse zoning with an inner facies containing dolerites, gabbros, and quartz diorites that is partially surrounded by an intermediate facies ranging from diorites to granodiorites, being both facies encircled by an outer border facies varying from quartz diorites to granodiorites and monzogranites (Figure 1C). It shows compelling evidence for hybridization between mafic and felsic magmas (see Figure 3H,I in [4]).

SHRIMP U-Pb zircon dating yields an age for the emplacement of the various intrusive bodies ranging from 334 to $320 \mathrm{Ma}$ (i.e., Visean-Bashkirian [4]).

According to Cambeses et al. [4], the inner facies from the VVP is alkaline (49-57 wt.\% $\mathrm{SiO}_{2}, 5-8$ wt.\% $\mathrm{Na}_{2} \mathrm{O}+\mathrm{K}_{2} \mathrm{O}$ ), enriched in $\mathrm{FeO}$ (range: 6-10 wt.\%) and $\mathrm{TiO}_{2}$ (range: $1.2-2.7 \mathrm{wt} . \%)$, whereas the border facies shows a calc-alkaline affinity (52-73 wt.\% $\mathrm{SiO}_{2}$, $2-8$ wt. $\% \mathrm{Na}_{2} \mathrm{O}+\mathrm{K}_{2} \mathrm{O}$ ) with a wide range of variation in $\mathrm{FeO} / \mathrm{MgO}$ (range: $0.5-4.2$ by weight) and $\mathrm{K}_{2} \mathrm{O}$ (range: $1-5 \mathrm{wt} . \%$ ). The intermediate facies is transitional sharing compositional characteristics of the two groups (see Figure 4 and Table 1 in [4]; see also [41,44-46]). $\varepsilon \mathrm{Nd}_{t}$ and ${ }^{87} \mathrm{Sr} /{ }^{86} \mathrm{Sr}_{\mathrm{t}}$ have a range of, respectively, -0.5 to -4.6 and $0.7054-0.7073$ for the calc-alkaline suite, and -1.5 to -4.6 and $0.7064-0.7068$ for the alkaline and transitional suites (see Figure 6 and Table 1 in [4]).

\section{Materials and Methods}

For this work, we studied four samples from the VVP: one dolerite (VAAW-20) with 48.63 wt. $\% \mathrm{SiO}_{2}, 2.33$ wt. $\% \mathrm{Na}_{2} \mathrm{O}$, and 2.75 wt.\% $\mathrm{K}_{2} \mathrm{O}$ from the alkaline inner facies; one diorite (VAAW-37) with 52.74 wt. $\% \mathrm{SiO}_{2}, 3.68$ wt. $\% \mathrm{Na}_{2} \mathrm{O}$, and 1.87 wt. $\% \mathrm{~K}_{2} \mathrm{O}$ from the transitional intermediate facies; one quartz diorite (VAAW-35) with $52.70 \mathrm{wt} . \% \mathrm{SiO}_{2}$, 2.44 wt. $\% \mathrm{Na}_{2} \mathrm{O}$, and $1.34 \mathrm{wt} . \% \mathrm{~K}_{2} \mathrm{O}$; and one monzogranite (VAAW-38) with $60.69 \mathrm{wt.} \%$ $\mathrm{SiO}_{2}, 3.53 \mathrm{wt} . \% \mathrm{Na}_{2} \mathrm{O}$, and $3.06 \mathrm{wt} . \% \mathrm{~K}_{2} \mathrm{O}$ from the calc-alkaline border facies. The location of all samples is given in [4] and in Figure 1C. Whole-rock major- and trace-elements, $\mathrm{Nd}$ and $\mathrm{Sr}$ radiogenic isotopes, and $\mathrm{U}-\mathrm{Pb}$ zircon dating of the studied samples are reported in Table 1 from [4].

Minerals were analyzed by wavelength dispersive spectrometry (WDS) using a CAMECA SX100 electron microprobe at the Centro de Instrumentación Científica (CIC, University of Granada, Spain) operated at $20 \mathrm{kV}$ accelerating voltage and $20 \mathrm{nA}$ beam current. Both natural and synthetic standards were used for the calibration: albite $(\mathrm{Na})$, diopside $(\mathrm{Si})$, wollastonite $(\mathrm{Ca})$, vanadinite $(\mathrm{Cl})$, sanidine $(\mathrm{K}), \mathrm{TiO}_{2}(\mathrm{Ti})$, rhodonite $(\mathrm{Mn})$, $\mathrm{CaF}_{2}(\mathrm{~F}), \mathrm{Fe}_{2} \mathrm{O}_{3}(\mathrm{Fe})$, and synthetic periclase $(\mathrm{Mg}), \mathrm{Al}_{2} \mathrm{O}_{3}(\mathrm{Al}), \mathrm{Cr}_{2} \mathrm{O}_{3}(\mathrm{Cr})$, and $\mathrm{NiO}(\mathrm{Ni})$. The precision was close to $4 \%$ for an analyte concentration of $1 \mathrm{wt} . \%$.

Systematic point analyses were carried out in resorbed cores, overgrowths and rims of plagioclase, as well as biotite and amphibole grains. Mineral formulas were normalized to 8 oxygen atoms for plagioclase, 22 oxygen atoms for biotite, and 23 oxygen atoms for amphibole (Table S1).

The $P$ - $T$ conditions of crystallization of the intermediate and border facies from the VVP were estimated in samples VAAW-35, VAAW-37, and VAAW-38 using the amphiboleplagioclase barometer from Molina et al. [15] (expression B; precision ca. $\pm 150-200 \mathrm{MPa}$ ) and the amphibole-plagioclase thermometer from Molina et al. [16] (expressions A1, A2 and B2; precision of ca. $\pm 50^{\circ} \mathrm{C}$ ). For sample VAAW-38, we also used the Al-in-hornblende 
barometer from Mutch et al. [17] (assumed precision of $\pm 100 \mathrm{MPa}$ ) as this rock sample bears the buffering assemblage quartz + plagioclase $+\mathrm{K}$ feldspar + amphibole + titanite (see below) that is required to buffer the amphibole composition [17]. For this purpose, we analyzed amphibole-plagioclase contacts and selected amphibole and plagioclase compositions from grain cores and overgrowths that encompass the whole compositional range of variation. The amphibole formula was calculated assuming 13 cations exclusive of $\mathrm{Ca}, \mathrm{Na}$, and $\mathrm{K}$ (13 eCNK method) for application of the amphibole-plagioclase barometer and the average $\mathrm{Fe}^{3+}$ method of [47] modified by [48] for the Al-in-hornblende barometer and the amphibole-plagioclase thermometer. The selected compositional data and the estimated $P$ - $T$ conditions are available in Table S2.

The $\mathrm{K}_{2} \mathrm{O}$ and $\mathrm{Na}_{2} \mathrm{O}$ contents of melts in equilibrium with amphibole were estimated as a function of the melt silica content, in the present work from 55 to $70 \mathrm{wt} . \%$, from amphibole composition using the expressions for amphibole-melt partition coefficients for $\mathrm{K}_{2} \mathrm{O}$ and $\mathrm{Na}_{2} \mathrm{O}-\mathrm{K}_{2} \mathrm{O}$ derived from Molina et al. [2]:

$$
\begin{gathered}
\log \mathrm{D}\left(\mathrm{K}_{2} \mathrm{O}\right)=-0.0247( \pm 0.0008) \mathrm{SiO}_{2}(w t . \%)+0.91( \pm 0.05), \\
\log \mathrm{D}\left(\mathrm{Na}_{2} \mathrm{O} / \mathrm{K}_{2} \mathrm{O}\right)=0.0202( \pm 0.0007) \mathrm{SiO}_{2}(w t . \%)-0.87( \pm 0.04) .
\end{gathered}
$$

\section{Petrography}

Dolerite VAAW-20 from the alkaline inner facies consists of a hypidiomorphic finegrained intergranular to subophitic aggregate of plagioclase (ca. 55 vol.\%) with andesine composition, clinopyroxene (ca. $20 \mathrm{vol} . \%$ ), biotite (ca. $20 \mathrm{vol} \%$ ), and accessory ilmenite, titanite, zircon, and apatite (Figure 2A,B).

Diorite VAAW-37 from the transitional intermediate facies is composed by a hypidiomorphic medium-grained intergranular aggregate of abundant subhedral prismatic plagioclase (ca. 55 vol.\%) and amphibole (ca. 30 vol.\%), tabular brown biotite (10 vol. \%), micrographic intergrowths of quartz (ca. 5 vol.\%) and K-feldspar ( $<5$ vol. $\%$ ), and accessory ilmenite, magnetite, titanite, zircon, and apatite (Figure $2 \mathrm{C}, \mathrm{D}$ ). Plagioclase exhibits resorbed cores of labradorite-andesine overgrown by andesine-oligoclase. Similarly, amphibole and biotite grains also experienced resorption, appearing anhedral cores of brown pargasite rimmed by green hornblendic amphibole and anhedral biotite inclusions replaced by the green amphibole (Figure 2D).

Quartz diorite VAAW-35 from the calc-alkaline border facies shows a hypidiomorphic medium-grained intergranular texture (Figure 2E), but with lower abundances of plagioclase (ca. 35 vol. $\%$ ) and biotite ( $<5$ vol. $\%$ ), and higher amphibole (ca. 50 vol. $\%$ ). $\mathrm{K}$-feldspar is absent in the mesostasis, which consists of anhedral quartz (ca. 5 vol.\%). It also contains very rare clinopyroxene that is resorbed by amphibole and an accessory mineral assemblage consisting of ilmenite, magnetite, titanite, zircon, and apatite. As in diorite VAAW-37, plagioclase shows anhedral cores, but with andesine composition, and overgrowths of oligoclase, and amphibole has anhedral, resorbed, brown cores of pargasite overgrown by green hornblendic amphibole (Figure 2E,F). Notably, biotite grains are systematically resorbed by the green amphibole (Figure 2E).

Monzogranite VAAW-38 from the calc-alkaline border facies contains abundant green amphibole (ca. $25 \mathrm{vol} \%$ ), plagioclase (ca. $30 \mathrm{vol} \%$ ), and K-feldspar (ca. $20 \mathrm{vol} \%$ ), moderate quartz (ca. $15 \mathrm{vol} \%$ ) and biotite (ca. $10 \mathrm{vol} \%$ ), and an accessory mineral assemblage consisting of ilmenite, magnetite, titanite, zircon, apatite, primary allanite, and epidote, and scarce clinopyroxene $(<1 \mathrm{vol} \%)$. It is inequigranular with coarse subhedral oikocrysts of perthitic K-feldspar with inclusions of euhedral plagioclase laths set in a medium-grained hypidiomorphic mesostasis consisting of subhedral plagioclase, subhedral to anhedral grains of biotite and amphibole, and anhedral interstitial quartz (Figure 2G,H). Some grains of plagioclase show resorbed cores of andesine, but no evidence for resorption of biotite and amphibole was found.

In the studied samples, it also appears scarce chlorite after biotite, actinolite replacing locally magmatic amphibole, and saussurite replacing the anorthite-rich cores of plagioclase. 


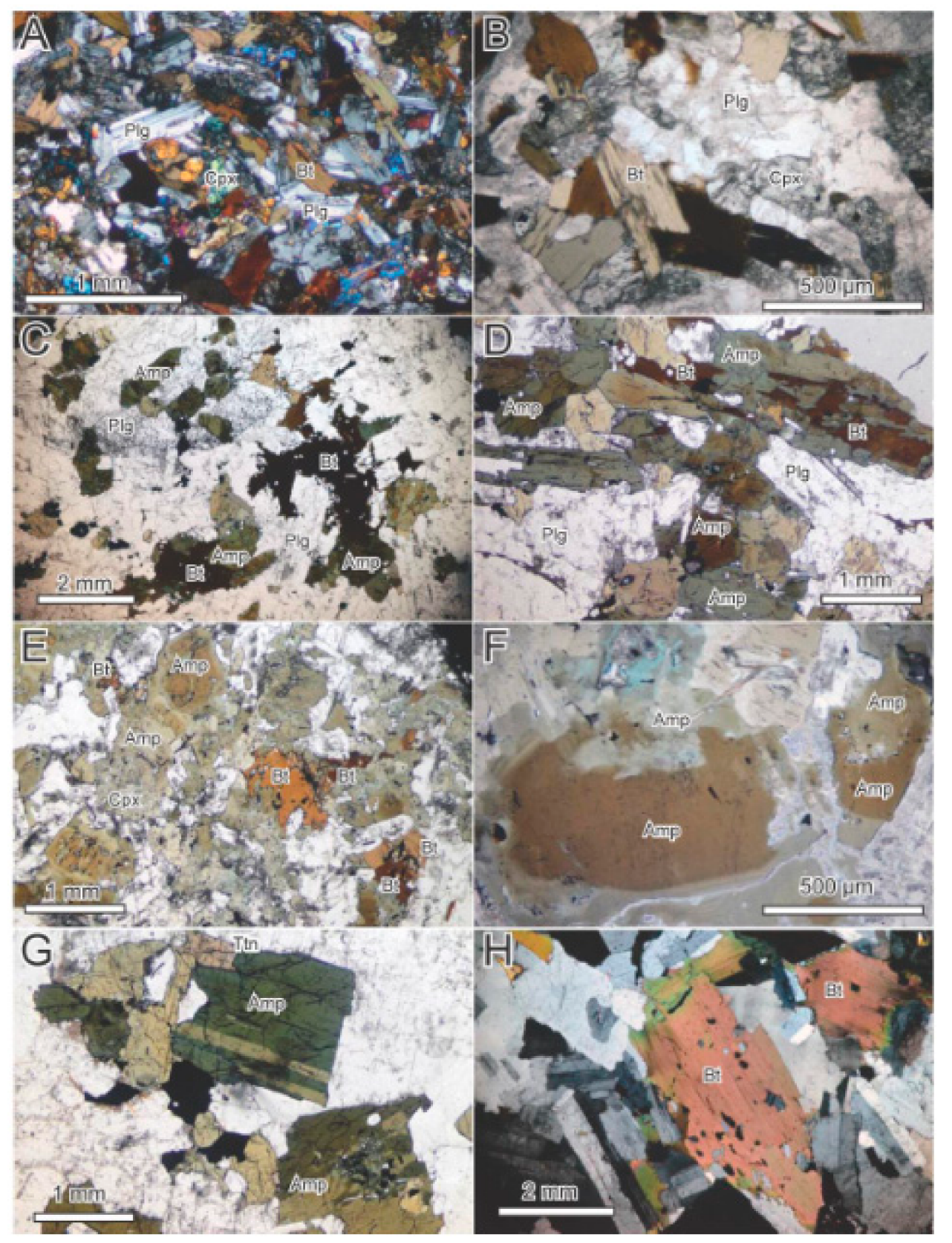

Figure 2. Representative microphotographs of the Valencia del Ventoso main pluton. (A) Hypidiomorphic fine-grained alkaline dolerite VAAW-20 from the inner facies xl; (B) detail of the dolerite VAAW-20 showing an intergranular aggregate of biotite, clinopyroxene, and plagioclase, ppl; (C) hypidiomorphic medium-grained intergranular texture in diorite VAAW-37 from the intermediate facies, ppl; (D) detail of the relationship between amphibole and biotite in diorite VAAW-37, the latter is included in green amphibole and shows evidence of resorption; note also zoned amphibole with anhedral brown core and green overgrowth, also evidencing resorption, ppl; (E) medium-grained quartz diorite VAAW-35 from the border facies; note zoned amphibole with anhedral, resorbed, brown core and green overgrowth and anhedral biotite inclusions resorbed by the green amphibole, ppl; (F) zoned amphibole grain with resorbed brown core and green overgrowth in quartz diorite VAAW-35, ppl; (G) medium-grained monzogranite VAAW-38 from the border facies with green amphibole, ppl; (H) detail of biotite in monzogranite VAAW-38, xp. Abbreviations: Amp: amphibole; Bt: biotite; Cpx: clinopyroxene; Plg: plagioclase; Qtz: quartz; Ttn: titanite (xp- and ppl-crossed polars and plane-polarized light, respectively). 


\section{Mineral Chemistry}

\subsection{Amphibole}

The compositions of amphibole in studied VVP samples are classified following [49] and displayed in Figure 3. The amphibole compositional data published by [44] for rocks from this pluton are also plotted and show similar trends.

Anhedral-resorbed cores and overgrowths of amphibole grains from transitional intermediate facies diorite VAAW-37 show systematic compositional variations tending to have the latter higher $\mathrm{Mg} /\left(\mathrm{Mg}+\mathrm{Fe}^{2+}\right)$ ratio (ranges: $0.44-0.51$ in cores and $0.50-0.57$ in overgrowths) and lower occupancies of $\mathrm{Al}^{\mathrm{IV}}$ (range: 1.53-1.84 apfu in cores and 1.28-1.56 apfu in overgrowths), total $\mathrm{Al}$ (range: 1.69-1.94 apfu in cores and 1.43-1.68 apfu in overgrowths), Ti (range: $0.36-0.46$ apfu in cores and $0.18-0.32$ apfu in overgrowth), and A-site (range: $0.65-0.87$ apfu in cores and $0.46-0.63$ apfu in overgrowths) (Table S1). Thus, they are hastingsite, magnesiohastingsite, and ferropargasite in the grain cores and magnesiohornblende and edenite in the overgrowths (Figure 3).

Amphibole from calc-alkaline border facies quartz diorite VAAW-35 shows similar compositional tendencies, but with more variable cation site occupancies (ranges: 0.60-1.67 apfu $\mathrm{Al}^{\mathrm{IV}}, 0.70-1.87$ apfu total $\mathrm{Al}, 0.089-0.39$ apfu Ti, and 0.16-0.65 apfu A-site), and slightly higher $\mathrm{Mg} /\left(\mathrm{Mg}+\mathrm{Fe}^{2+}\right)$ ratio (range: $\left.0.57-0.73\right)$ (Table S1). Accordingly, it is present pargasite and magnesiohastingsite in the grain cores and magnesiohornblende in the overgrowths, whereas the rim compositions extend towards actinolite, because of local alteration of magmatic amphibole (Figure 3).
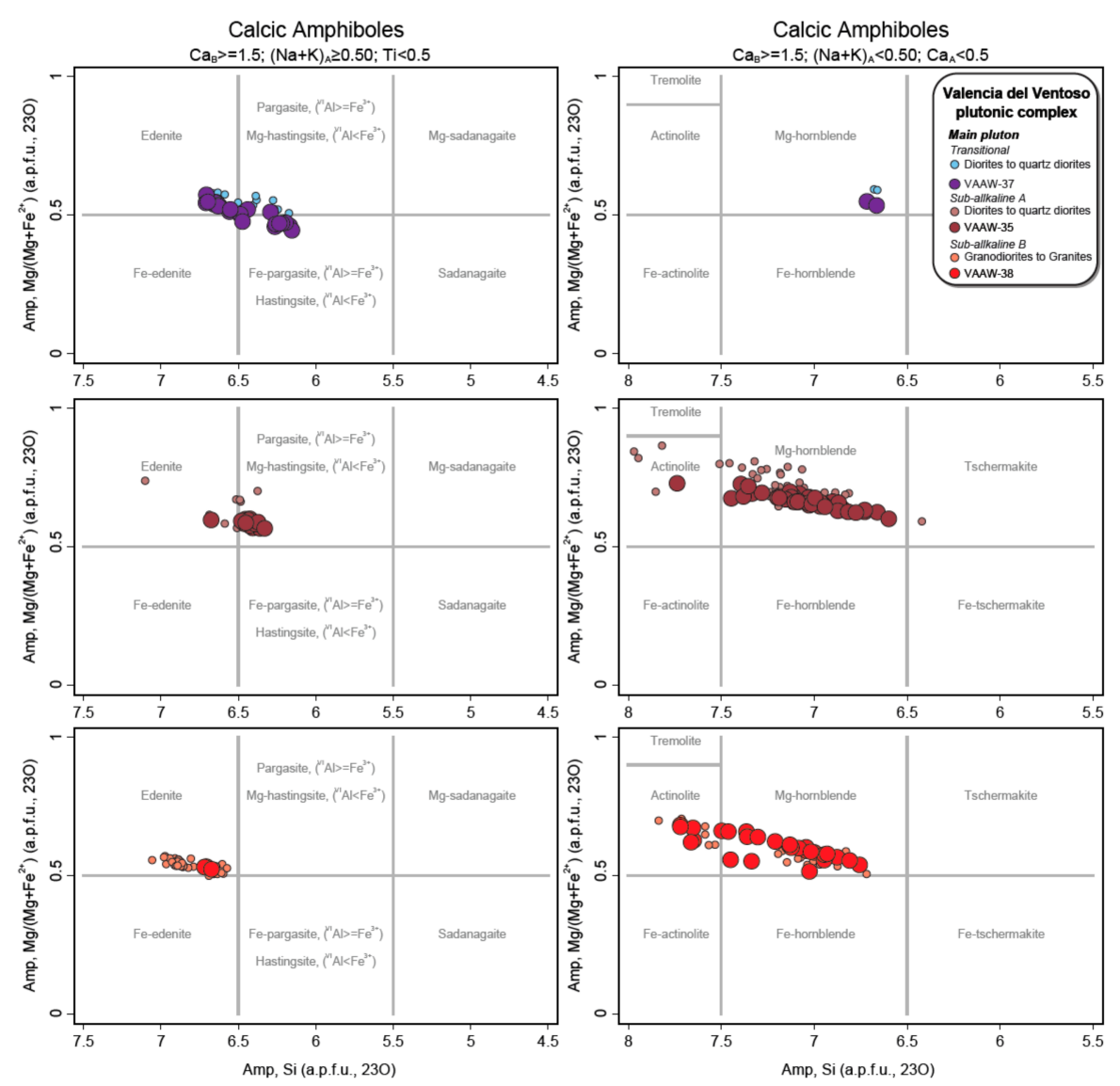

Figure 3. Classification of amphiboles from intermediate and border facies rocks from the Valencia del Ventoso main pluton following the criteria proposed by [49]. Compositional data of amphibole from [44] (smaller lighter symbols) are shown for comparison.

Amphibole from calc-alkaline border facies monzogranite VAAW-38 achieves lower occupancies in $\mathrm{Al}^{\mathrm{IV}}$ ( $\left.<1.33 \mathrm{apfu}\right)$, total $\mathrm{Al}(<1.46 \mathrm{apfu}), \mathrm{Ti}(<0.20 \mathrm{apfu})$, and A-site $(<0.57 \mathrm{apfu})$ 
(Table S1), thus varying from edenite and magnesiohornblende to actinolite in altered sites (Figure 3).

\subsection{Biotite}

Biotite has annite composition with $\mathrm{Mg} /\left(\mathrm{Mg}+\mathrm{Fe}^{2+}\right)$ ratios with ranges of $0.47-0.49$ in dolerite VAAW-20, 0.47-0.49 in diorite VAAW-37, 0.45-0.52 in quartz diorite VAAW-35, and $0.45-0.50$ in monzogranite VAAW-38 (Table S1).

Remarkably, the compositions of resorbed grains of biotite from diorite VAAW-37 and quartz diorite VAAW-35 are similar to those from alkaline dolerite VAAW-20. They are characterized by a deficient tetrahedral-site occupancy, i.e., $\mathrm{Si}+\mathrm{Al}<8$ (normalization to 22 oxygen atoms) (Figure 4$)$, which is a distinctive feature of potassic magmatism (see $[5,50]$ for a discussion).
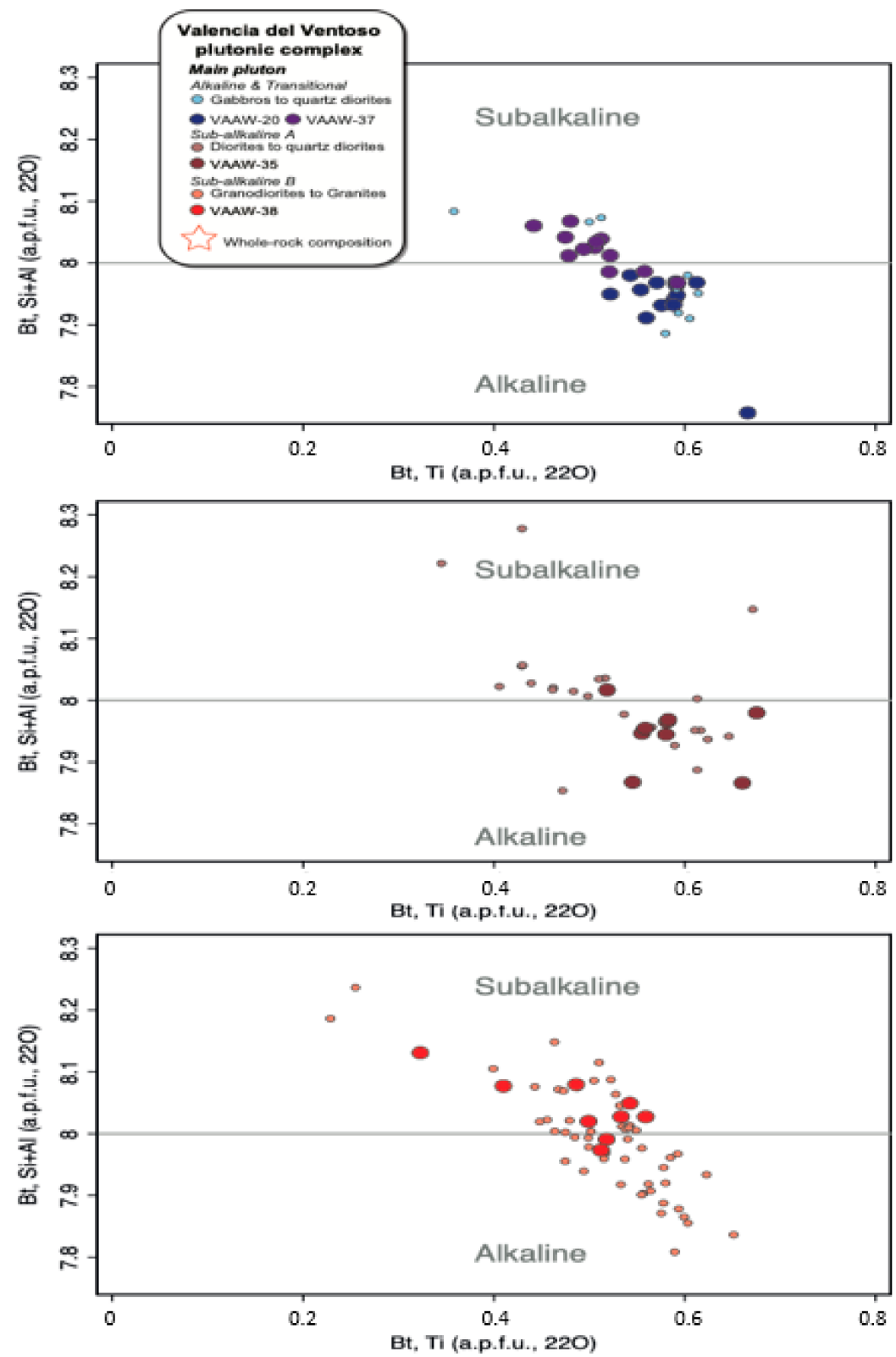

Figure 4. Composition of biotite from the inner, intermediate, and border facies rocks from the Valencia del Ventoso main pluton. Alkaline and subalkaline fields as indicated in $[5,50]$. Compositional data of biotite from [44] (smaller lighter symbols) are shown for comparison. 


\subsection{Plagioclase}

Plagioclase composition is relatively homogeneous in dolerite VAAW-20 being andesine with $\mathrm{An}_{40-45}$. In the other rock facies, it varies as follows: (1) diorite VAAW-37: labradorite-andesine with ca. $\mathrm{An}_{42-52}$ in anhedral cores to andesine with ca. $\mathrm{An}_{30-37}$ in overgrowths; (2) quartz diorite VAAW-35: andesine with ca. $A n_{35-40}$ in anhedral cores to andesine-oligoclase with ca. $\mathrm{An}_{27-30}$ in overgrowths; and (3) monzogranite VAAW38: andesine with ca. $\mathrm{An}_{42}$ in anhedral cores to oligoclase with $\mathrm{An}_{25-27}$ in overgrowths (Table S1).

\section{Thermobarometric Estimations}

The amphibole-plagioclase thermometer from [16] gave no reliable results for amphibole and plagioclase overgrowths of samples VAAW-35 and VAAW-37 because their compositions lie outside the limits of application of the calibrations (see [16] for details). Therefore, for these samples we only report the $P$ - $T$ conditions of crystallization of antercrystic amphibole and plagioclase estimated with the expressions by Molina et al. [15,16]. Three groups were distinguished for each sample whose compositional ranges are indicated in Figure 5.

For sample VAAW-38, with nearly constant plagioclase overgrowth composition, calculations were performed for a fix anorthite content of 0.27 and a wide range of amphibole compositions that were grouped into two types with compositional limits shown in Figure 5. The amphibole-plagioclase barometer from [15] did not yield good results for the amphibole-plagioclase pairs from this sample because their compositions are not suitable for the calculations as shown in Figure 5A,B. For that reason, the $P-T$ conditions were estimated using the amphibole-plagioclase thermometer from [16] and the Al-in-hornblende barometer from [17].

The estimated P-T conditions are displayed in Figure 5C and reported in Table S2. The temperature estimates for the various groups distinguished in sample VAAW-35 are relatively close, ranging from 704 to $790{ }^{\circ} \mathrm{C}$. For sample VAAW-37, they are more variable ranging as follows: $694-818{ }^{\circ} \mathrm{C}$ in GA, $707-836{ }^{\circ} \mathrm{C}$ in GB, and $718-852{ }^{\circ} \mathrm{C}$ in GC. Temperature estimates for GB from sample VAAW-38 are subsolidus lying outside the temperature range of the calibration (c.f., [16]), whereas those for GA, with the highest amphibole Ti contents of the sample, cluster around $621-653{ }^{\circ} \mathrm{C}$. It is interesting to note that, despite the compositional pairs depart slightly from the optimal region of use (see [16] for details), the temperature estimates do not show systematic variations with amphibole Ti occupancy (Figure 5D), whose recommended values are $<0.4$ apfu.

Pressure estimates for GA from sample VAAW-38 are close to 290-310 MPa, whereas in samples VAAW35 and VAAW-37, they are more variable ranging, respectively, from 200 to $390 \mathrm{MPa}$ and from 130 to $370 \mathrm{MPa}$.

According to these results, the best $P$ - $T$ estimates for these samples cluster around $280 \mathrm{MPa}$ and $760{ }^{\circ} \mathrm{C}$ in both quartz diorite VAAW35 and diorite VAAW-37 and $300 \mathrm{MPa}$ and $640{ }^{\circ} \mathrm{C}$ in monzogranite VAAW38 (Figure 6). 

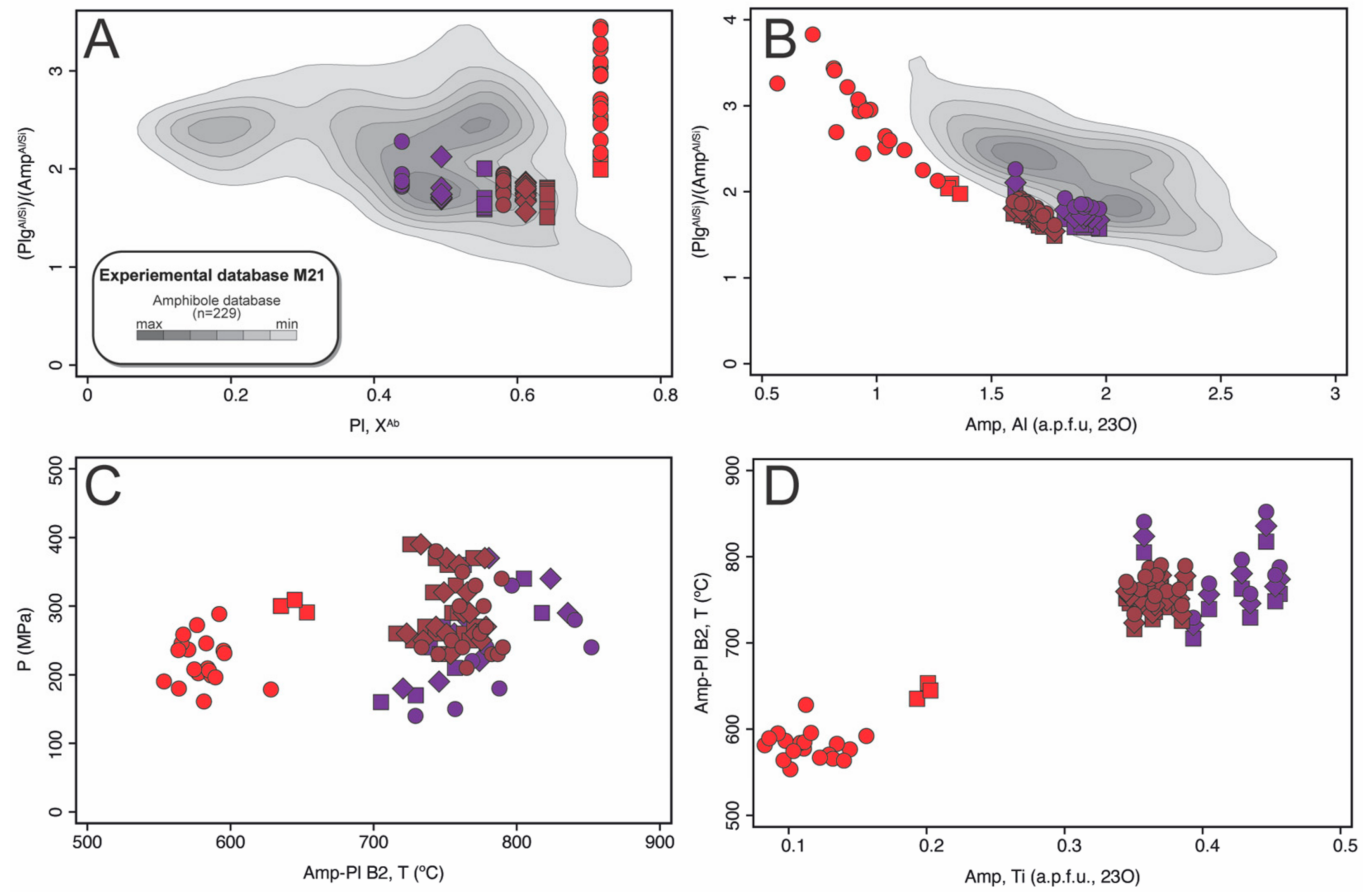

\begin{tabular}{|c|c|c|}
\hline & $\begin{array}{l}\text { Valencia del Ventoso plutonic complex } \\
\text { Main pluton }\end{array}$ & \\
\hline Transitional, VAAW-37 & Sub-alkaline A, VAAW-35 & Sub-alkaline B, VAAW-38 \\
\hline $\boldsymbol{\square}_{(\mathrm{Ti}, 0.358-0.456, \mathrm{~K}}^{\mathrm{GA}, \mathrm{Amp}} 0.209-0.252$, apfu)-PI (An 0.42) & $\boldsymbol{\square}_{(\mathrm{Ti}, 0.345-0.387, \mathrm{~K} 0.171-0.199, \text { apfu)-PI (An 0.35) }}^{\text {GA, Amp }}$ & $\mathbf{\square}_{(\mathrm{Ti} 0.193-0.203, \mathrm{~K} 0.201-0.214, \mathrm{apfu})-\mathrm{Pl}(\mathrm{An} 0.27)}^{\mathrm{GA}, \mathrm{mp}}$ \\
\hline $\begin{array}{l}\text { GB, Amp } \\
\text { (Ti 0.358-0.456, K 0.209-0.252, apfu)-PI (An 0.47) }\end{array}$ & 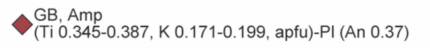 & $\begin{array}{l}\text { GB, Amp } \\
\text { (Ti } 0.083-0.156, K \text { K } 0.098-0.197, \text { apfu)-PI (An 0.27) }\end{array}$ \\
\hline $\begin{array}{l}\text { GC, Amp } \\
\text { (Ti 0.358-0.456, K 0.209-0.252, apfu)-PI (An 0.52) }\end{array}$ & $\begin{array}{l}\text { GC, Amp } \\
\text { (Ti } 0.345-0.387, K \text { K } 0.171-0.199 \text {, apfu)-PI (An 0.40) }\end{array}$ & \\
\hline
\end{tabular}

Figure 5. Thermobarometric estimations in intermediate and border facies rocks from the Valencia del Ventoso main pluton. (A,B) $\mathrm{Al} / \mathrm{Si}$ partitioning between plagioclase and amphibole versus albite component in plagioclase and $\mathrm{Al}$ occupancy in amphibole from the selected amphibole-plagioclase compositional pairs, also shown bivariate kernel density estimations after [51] of compositional data of synthetic amphibole compiled by [16]; (C) $P$-T estimations for the selected amphibole-plagioclase compositional pairs using expressions by $[15,16]$ for samples VAAW-37 and VAAW-35 and by $[16,17]$ for sample VAAW-38; (D) temperature estimates (expression B2 from [16]) versus Ti occupancy in amphibole.

\section{Discussion}

\subsection{Conditions of Magma Crystallization}

Spear [52] demonstrated that for a fixed bulk composition the $\mathrm{Mg} /\left(\mathrm{Mg}+\mathrm{Fe}^{2+}\right)$ ratio of amphibole shows a strong positive dependence on $\mathrm{fO}_{2}$. Accordingly, the increase of the $\mathrm{Mg} /\left(\mathrm{Mg}+\mathrm{Fe}^{2+}\right)$ ratio of amphibole with increasing Si occupancy in the three studied samples (Figure 3) implies an increase of $\mathrm{fO}_{2}$, which was relatively high (Figure 7); this is consistent with the presence of ilmenite + magnetite in the three rock samples (c.f. $[53,54])$. This amphibole compositional trend is characteristic of an oxidation process during magmatic differentiation in plutonic rocks as proposed by Czamanske and Wones [55]. These authors indicated that it is produced because $\mathrm{H}_{2} \mathrm{O}$ acts as an oxidizing agent, via dissociation and loss of $\mathrm{H}_{2}$, after its separation from the melt, providing an indirect evidence for a relatively high $\mathrm{H}_{2} \mathrm{O}$ content in the magma. This is consistent with the relatively low temperatures estimated for the various rock types that are close to those for the wet saturated solidus for granodiorites and diorites (Figure 6). 


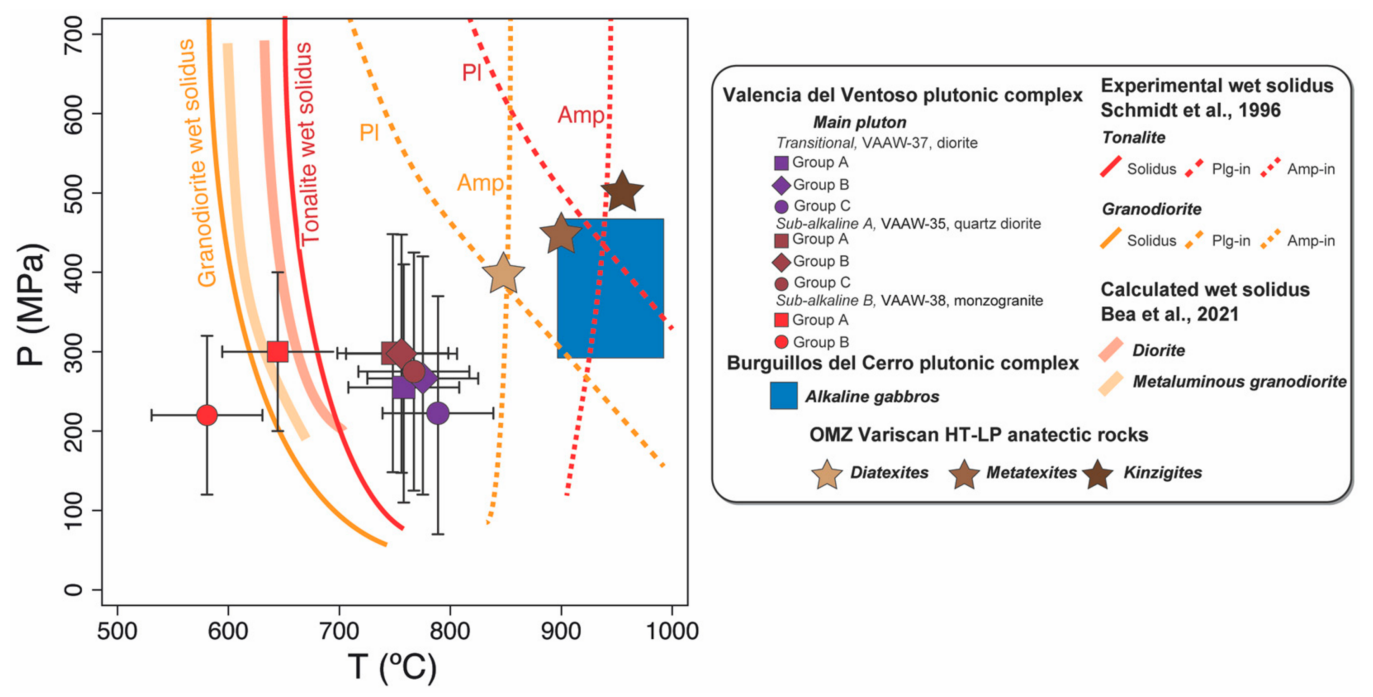

Figure 6. Average $P$ - $T$ estimates in intermediate and border facies rocks from the Valencia del Ventoso main pluton using amphibole-plagioclase thermobarometry and Al-in-hornblende barometry. P-T estimates for Variscan alkaline gabbros and anatectic metasediments from the OMZ also shown (after [3]). Wet solidus and plagioclase-in and amphibole-in reactions in synthetic tonalite and granodiorite systems as experimentally established by [56], and wet solidus for metaluminous granodiorite and diorite as calculated by [57] using rhyolite-MELTS [58].
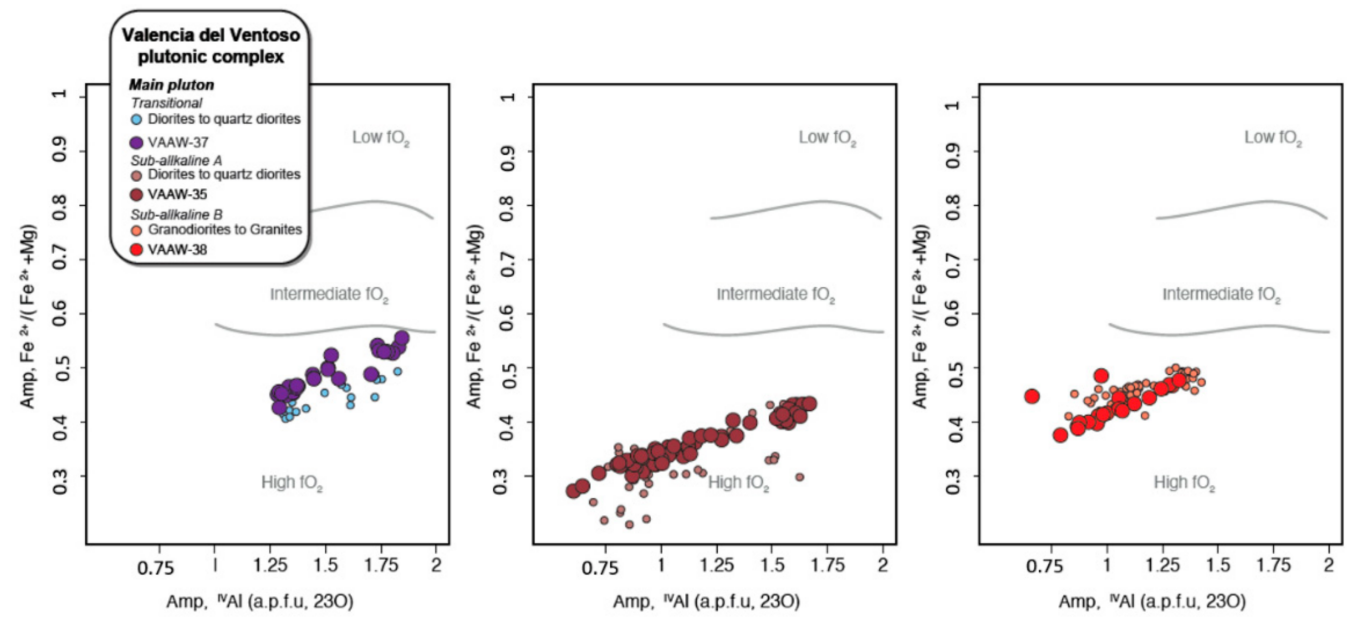

Figure 7. $\mathrm{Fe}^{2+} /\left(\mathrm{Fe}^{2+}+\mathrm{Mg}\right)$ versus $\mathrm{Al}^{\mathrm{IV}}$ occupancy in amphibole from intermediate and border facies rocks from the Valencia del Ventoso main pluton with oxygen fugacity fields as proposed by Anderson and Smith [54].

8.2. Magma Compositional Evolution in the Valencia del Ventoso Main Pluton: Constraints from Biotite and Amphibole Compositional Relationships

The reverse zoning exhibited by the Valencia del Ventoso main pluton suggests that the magma feeding system evolved from calc-alkaline to transitional and alkaline compositions. Cambeses et al. $[4,5]$ indicated that the Variscan calc-alkaline magmas from the OMZ were formed by hybridization of mantle-derived mafic alkaline magmas with crustal-derived felsic magmas generated at depth due to crustal anatexis caused by heat transferred from the IRB intrusion in the middle crust (Figure 7).

In order to seek evidence for the alkaline component in the Valencia del Ventoso main pluton, below we discuss the compositional relationships of amphibole from the VVP samples and estimate the $\mathrm{Na}_{2} \mathrm{O}$ and $\mathrm{K}_{2} \mathrm{O}$ contents as a function of silica of the melts that were saturated in amphibole using the expressions (1) and (2) derived by [2]. 
For using this method, we must discriminate first between primary and secondary amphibole. We screened out secondary amphiboles using constraints from relationships of $\mathrm{TiO}_{2}$ with $\mathrm{Na}_{\mathrm{A}}$ (A-site Na) $+\mathrm{K}$ and $\mathrm{Al}^{\mathrm{IV}}$ as proposed by [2] (Figure 8).

In agreement with these authors, the supersolidus amphibole from an experimental database compiled by Molina et al. [16] defines compositional fields for magmatic amphibole in the $\mathrm{Na}_{\mathrm{A}}+\mathrm{K}$ versus $\mathrm{TiO}_{2}$ and $\mathrm{Al}^{\mathrm{IV}}$ versus $\mathrm{TiO}_{2}$ diagrams (Figure 8). The limits of these fields suggest that amphibole with $<0.7 \mathrm{wt} . \% \mathrm{TiO}_{2}$ and both $<0.5 \mathrm{apfu} \mathrm{Na}_{\mathrm{A}}+\mathrm{K}$ and $<0.9$ apfu $\mathrm{Al}^{\mathrm{IV}}$ can likely be secondary.
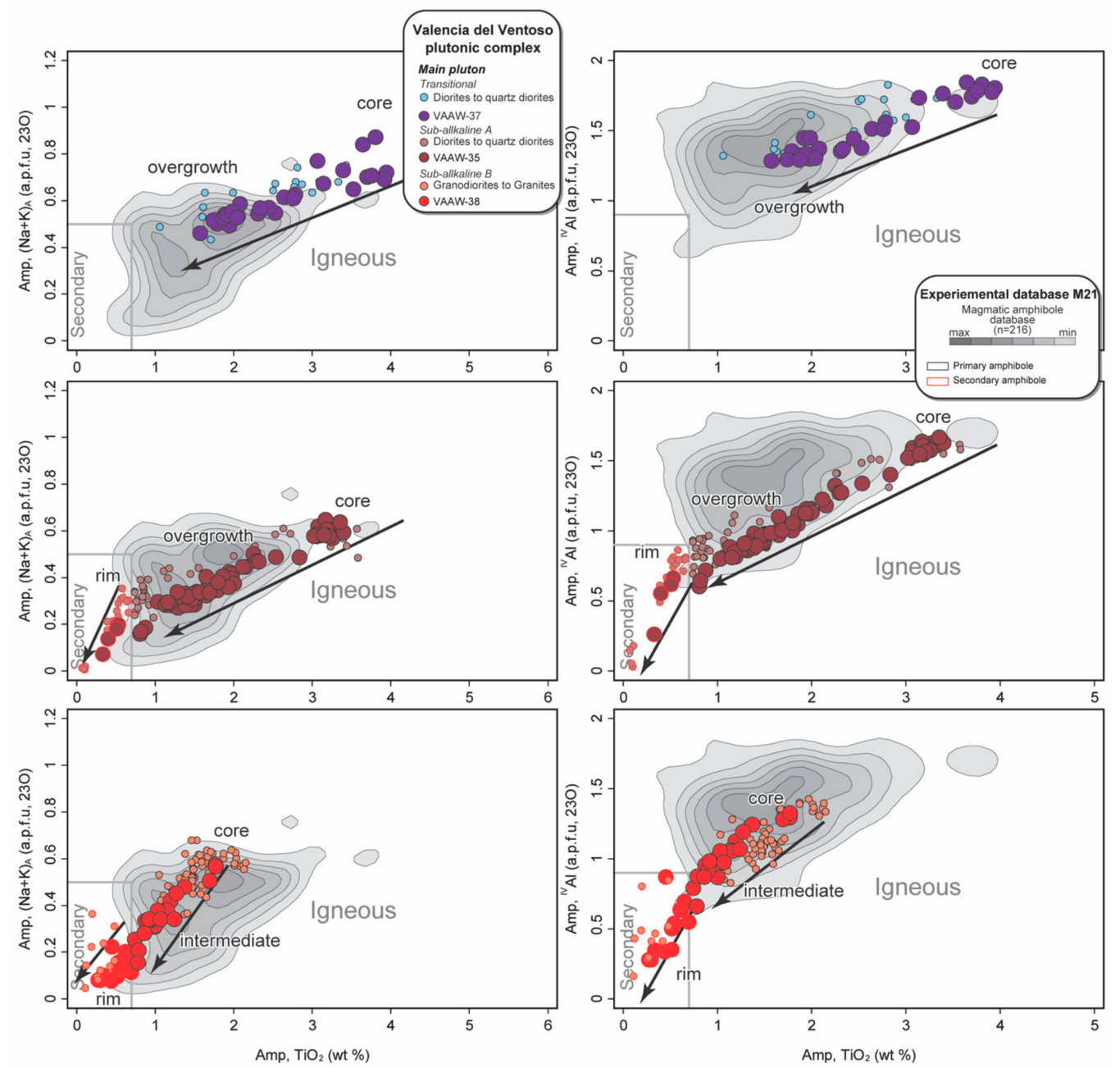

Figure 8. Composition of amphibole from intermediate and border facies rocks from the Valencia del Ventoso main pluton. $\mathrm{Na}_{\mathrm{A}}+\mathrm{K}(\mathrm{apfu})$ versus $\mathrm{TiO}_{2}$ (wt.\%) and $\mathrm{Al}^{\mathrm{IV}}$ (apfu) versus $\mathrm{TiO}_{2}$ (wt.\%). Also shown are bivariate kernel density estimations after [51] of compositional data of synthetic supersolidus amphibole compiled by [16]. The diagrams show a well-defined compositional field for magmatic amphibole thus permitting a discrimination between secondary and primary amphiboles (see further discussion in [2]). The arrows represent the main compositional trends of amphibole compositions. Compositional data of amphibole from [44] (smaller lighter symbols) are shown for comparison.

The relationships of $\mathrm{TiO}_{2}$ with $\mathrm{Al}_{2} \mathrm{O}_{3}, \mathrm{~K}_{2} \mathrm{O}$, and $\mathrm{Na}_{2} \mathrm{O}$ for the selected primary compositions and the calculated melt alkali contents are displayed in Figures 9 and 10, respectively.

Compositional relationships for anhedral brown grain cores of high-Ti amphibole from transitional diorite VAAW-37 suggest a melt with alkaline affinity (Figure 9). Accordingly, the calculated melt compositions have an alkaline affinity with high- to ultra-K and $\mathrm{K}_{2} \mathrm{O} / \mathrm{Na}_{2} \mathrm{O}$ ratios $>1.5$ (Figure 10). Amphibole rim compositions for this sample lie in the non-discriminating alkaline + subalkaline-melt field; however, the calculated composi- 
tions for melt silica contents $<70$ wt. $\%$ are subalkaline, but still high- $\mathrm{K}$, with $\mathrm{K}_{2} \mathrm{O} / \mathrm{Na}_{2} \mathrm{O}$ ratios $>0.5$.
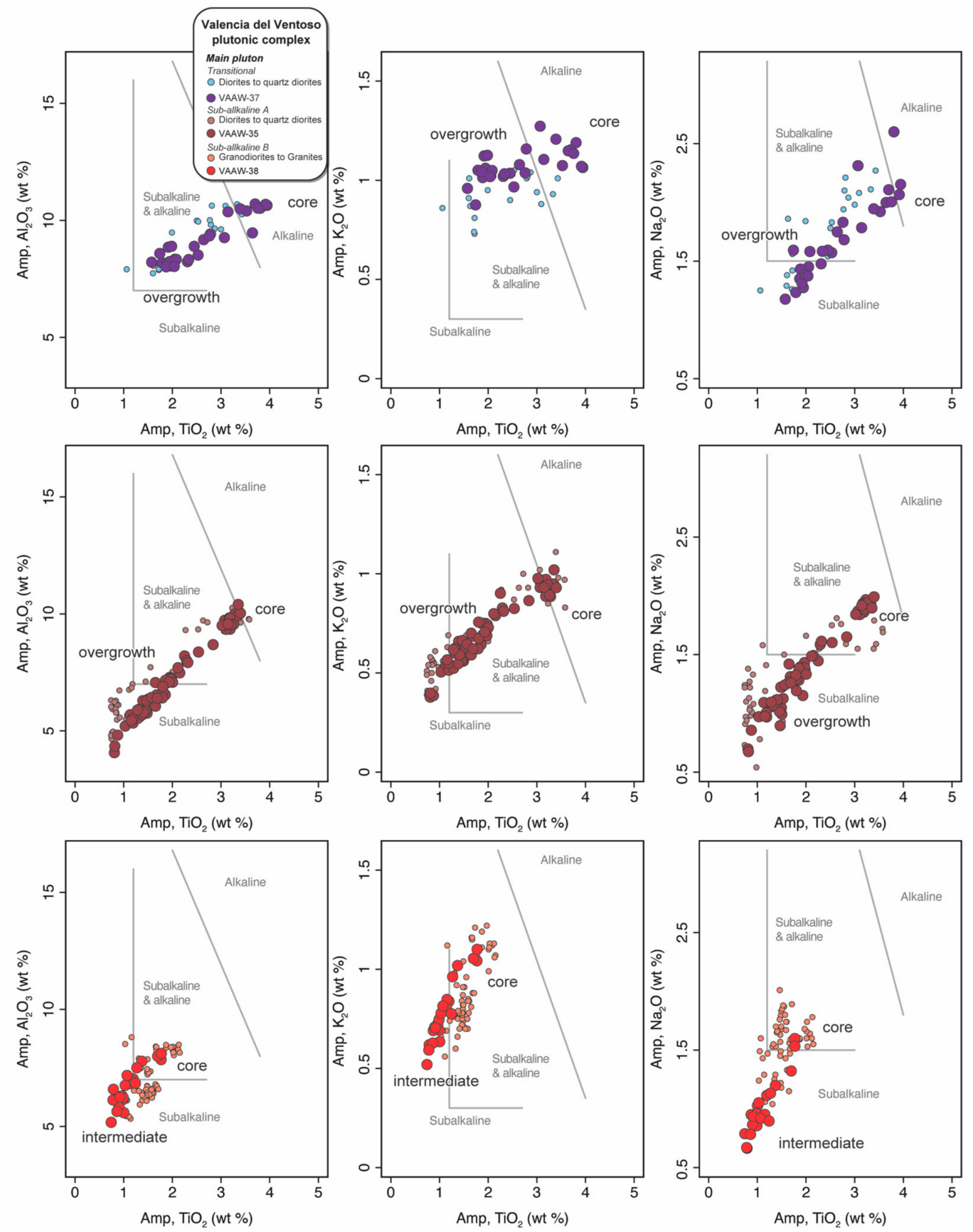

Figure 9. Composition of magmatic amphibole from intermediate and border facies rocks from the Valencia del Ventoso main pluton. $\mathrm{Al}_{2} \mathrm{O}_{3}$ (wt.\%) versus $\mathrm{TiO}_{2}$ (wt. $\%$ ), $\mathrm{K}_{2} \mathrm{O}$ (wt.\%) versus $\mathrm{TiO}_{2}$ (wt.\%), and $\mathrm{Na}_{2} \mathrm{O}$ (wt.\%) versus $\mathrm{TiO}_{2}$ (wt.\%) with compositional fields for alkaline and subalkaline melts as proposed by [2]. Compositional data of amphibole from [44] (smaller lighter symbols) are shown for comparison.

The compositions of anhedral grain cores of amphibole from calc-alkaline quartz diorite VAAW-35, with slightly lower $\mathrm{Ti}$ contents, lie in the non-discriminating alkaline + subalkaline-melt field of the $\mathrm{Al}_{2} \mathrm{O}_{3}-\mathrm{TiO}_{2}$ and $\mathrm{Na}_{2} \mathrm{O}-\mathrm{TiO}_{2}$ diagrams and in the alkaline-melt field of the $\mathrm{K}_{2} \mathrm{O}-\mathrm{TiO}_{2}$ diagram (Figure 9). The calculated melt compositions for silica contents $<65 \mathrm{wt}$. $\%$ are subalkaline, but straddling the alkaline-subalkaline boundary, with medium- to high-K affinities (Figure 10). Both amphibole and calculated melt 
compositional relationships for rim compositions are consistent with a subalkaline-melt affinity with medium- to high- $\mathrm{K}$ and $\mathrm{a}_{2} \mathrm{O} / \mathrm{Na}_{2} \mathrm{O}$ ratio higher than that for the whole-rock composition. It is interesting to note that the composition of the more evolved monzogranite VAAW-38 from the same rock unit shows total alkali and $\mathrm{K}_{2} \mathrm{O}$ contents consistent with the melts calculated for amphibole grain cores of sample VAAW-35, but a $\mathrm{K}_{2} \mathrm{O} / \mathrm{Na}_{2} \mathrm{O}$ ratio that is more consistent with melts calculated for rim compositions. This discrepancy suggests that the monzogranite magma could not be derived by simple crystal fractionation of a quartz dioritic parental magma. Accordingly, the crustal signature of radiogenic isotopes is higher in monzogranite VAAW-38 than in quartz diorite VAAW-35 (Table 1 in [4]).

A

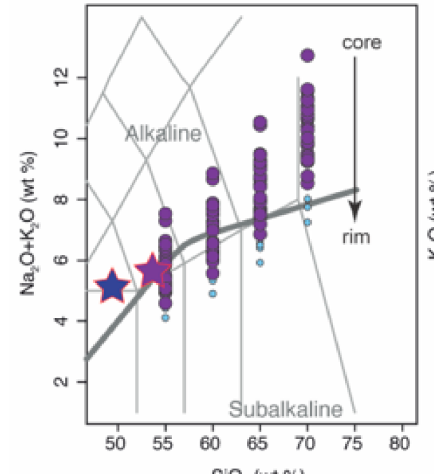

$\mathrm{SiO}_{2}$ (wt \%)
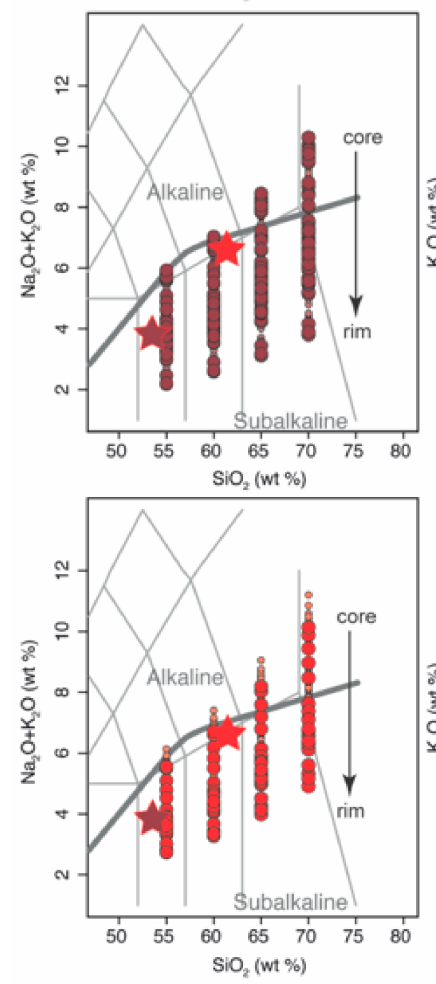
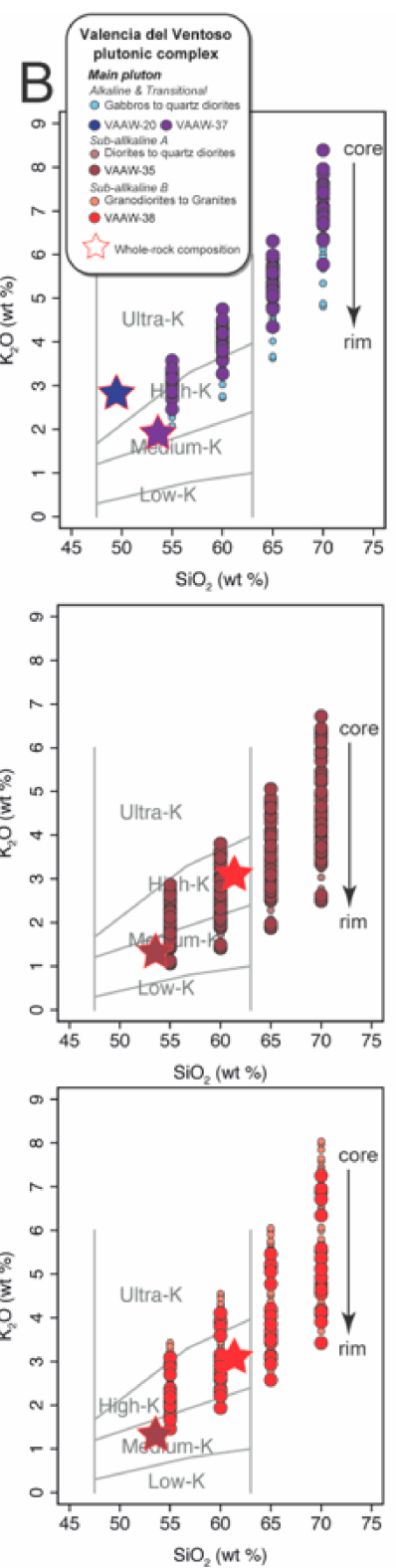
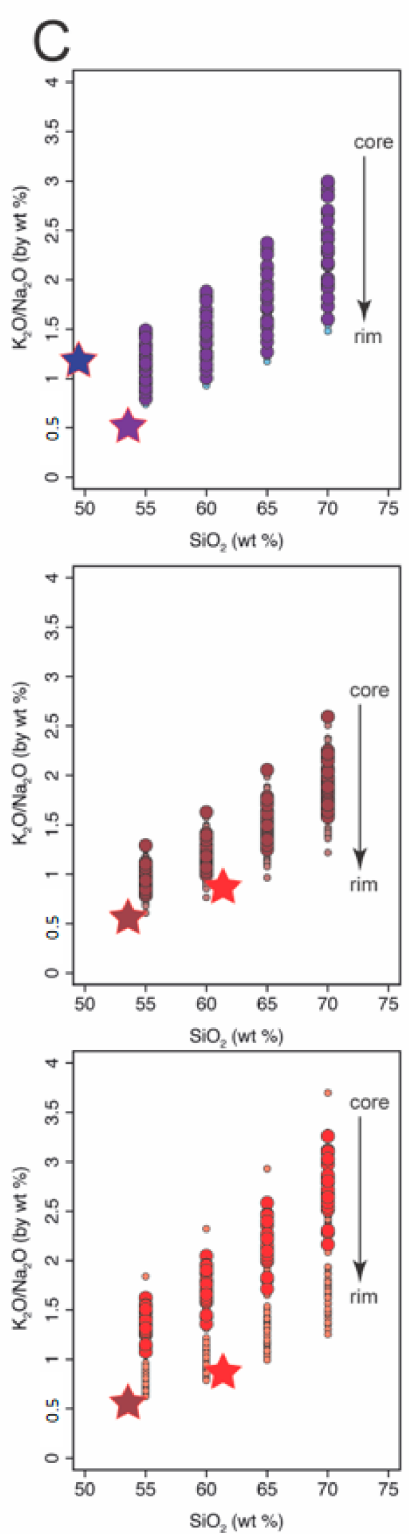

Figure 10. Estimated composition of melts in equilibrium with amphibole from intermediate and border facies rocks from the Valencia del Ventoso main pluton. Compositions were estimated using the partition coefficient expressions derived from [2]. (A) Total alkali versus $\mathrm{SiO}_{2}$ (wt.\%) (TAS); (B) $\mathrm{K}_{2} \mathrm{O}$ (wt.\%) versus $\mathrm{SiO}_{2}$ (wt.\%); (C) $\mathrm{K}_{2} \mathrm{O} / \mathrm{Na}_{2} \mathrm{O}$ versus $\mathrm{SiO}_{2}$ (wt.\%). Liquid compositions estimated for compositional data of amphibole from [44] (smaller lighter symbols) are shown for comparison. Stars are the whole rock composition of the samples VAAW-20, VAAW-35, VAAW-37, and VAAW-38 taken from [4]. 
Amphibole compositions from monzogranite VAAW-38 lie in the subalkaline-melt or in the non-discriminating alkaline + subalkaline-melt compositional fields of diagrams from Figure 9. Calculated melt compositions are mostly subalkaline with a high- or ultra-K character and $\mathrm{K}_{2} \mathrm{O} / \mathrm{Na}_{2} \mathrm{O}$ ratio of $>1$ for all amphibole compositions excepting Ti-richer grain cores that are alkaline to transitional (Figure 10).

The resorption of biotite by amphibole observed in the transitional diorite VAAW-37 and the calc-alkaline quartz diorite VAAW-35 from, respectively, the intermediate and border facies could be explained by some of the following mechanisms: (1) reversal from the Bowen's discontinuous reaction series that is characteristic of potassic magmas $[2,59,60]$ (i.e., primocryst, closed system behavior); (2) assimilation of country-rocks (i.e., xenocryst, open system behavior); and (3) cannibalization of phenocrysts coming from a different magma (antecryst, open system behavior). The medium-K affinity of the calc-alkaline quartz diorite VAAW-35 precludes a primocrystic origin for biotite (compare with the ultra-K affinity of alkaline dolerite VAAW-20; Figure 10B), being more likely an open system behavior. Accordingly, the similar Si-Al deficiency shown by resorbed grains of biotite from these samples and from dolerite VAAW-20 (Figure 4) is more consistent with the entrance into the calc-alkaline and transitional magmas of biotite grains derived from the alkaline magma, thus favoring an antecrystic origin. In the same way, the inferred compositions for melts saturated in high-Ti amphibole from samples VAAW-35 and VAAW-37 are also consistent with derivation from an alkaline to mildly alkalic magma. Therefore, these relationships suggest that anhedral biotite, high-Ti amphibole, and labradorite-andesine from diorites and quartz diorites could represent antecrysts derived from an alkaline magma that were entrapped into a subalkaline magma. The similar pressure estimates for amphibole from monzogranite VAAW-38 and for antecrystic amphibole-plagioclase pairs from diorite VAAW-37 and quartz diorite VAAW-35 further suggest that hybridization did most likely occur at the depth of magma emplacement. Therefore, according to the sequence of intrusion implied by the reverse zoning of the VVP, the hybrid transitional diorites and subalkaline quartz diorites could be produced during replenishment of the magma chamber by the alkaline magma. The involvement of the alkaline component in the calc-alkaline monzogranite from the border facies was probably minor as there is not clear textural evidence of mineral resorption in sample VAAW-38, except for scarce plagioclase grains with anhedral cores. However, some amphibole compositions predict high-K alkaline to transitional melt compositions as in quartz diorite VAAW-35.

\section{Conclusions}

The VVP from the OMZ is a reversely zoned intrusion that consists of an inner facies with alkaline dolerites, gabbros, and quartz diorites, partially surrounded by an intermediate facies with transitional diorites to granodiorites that are encircled by an outer border facies with calc-alkaline quartz diorites, granodiorites, and monzogranites.

The magmas crystallized under oxidizing conditions at relatively low temperatures (range: $640-760{ }^{\circ} \mathrm{C}$ ) and ca. $280-300 \mathrm{MPa}$, implying near $\mathrm{H}_{2} \mathrm{O}$-saturated conditions.

Replenishment of a calc-alkaline magma chamber by a biotite + high-Ti pargasitehastingsite + labradorite-andesine laden alkaline magma caused hybridization and dispersion of the phenocryst load into the calc-alkaline magma.

Reaction of the antecrystic minerals with the hybrid magma caused resorption and overgrowth of hornblendic amphibole on biotite and high-Ti pargasite-hastingsite, and of andesine-oligoclase on labradorite-andesine.

Amphibole-melt compositional relationships in antecrystic high-Ti amphibole reveal the interaction of calc-alkaline magmas with high- to ultra-K alkaline to mildly alkalic magmas.

Supplementary Materials: The following are available online at https: / www.mdpi.com/article/ 10.3390/min11040431/s1, Table S1: Amphibole, biotite, and plagioclase compositions, Table S2: Summary of P-T conditions. 
Author Contributions: Conceptualization, A.C. and J.F.M.; methodology, A.C. and J.F.M.; software, A.C.; data curation, A.C.; writing-original draft preparation, A.C., C.L. and J.F.M.; writing-review and editing, A.C., J.F.M., I.M., C.L., J.A.M., P.M. and F.B.; funding acquisition, F.B. and P.M. All authors have read and agreed to the published version of the manuscript.

Funding: This research was funded by Ministerio de Economía y Competitividad (Gobierno de España), grant numbers: CGL2008-02864, CGL2013-40785-P and CGL2017-84469-P, and Consejería de Economía y Conocimiento (Junta de Andalucía), grant numbers: RNM1595 and RNM2163.

Data Availability Statement: The data of this study are available in the Supplementary Materials.

Acknowledgments: We thank the three anonymous reviewers and the academic editor for the thorough revision and the insightful comments.

Conflicts of Interest: The authors declare no conflict of interest.

\section{References}

1. Bea, F.; Gallastegui, G.; Montero, P.; Molina, J.F.; Scarrow, J.; Cuesta, A.; González-Menéndez, L. Contrasting high-Mg, high-K rocks in Central Iberia: The appinite-vaugnerite conundrum and their (non-existent) relation with arc magmatism. J. Iber. Geol. 2021. [CrossRef]

2. Molina, J.F.; Scarrow, J.H.; Montero, P.; Bea, F. High-Ti amphibole as a petrogenetic indicator of magma chemistry: Evidence for mildly alkalic-hybrid melts during evolution of Variscan basic-ultrabasic magmatism of Central Iberia. Contrib. Mineral. Petrol. 2009, 158, 69-98. [CrossRef]

3. Cambeses, A. Ossa-Morena Zone Variscan ‘Calc-Alkaline' Hybrid Rocks: Interaction of Mantle- and Crutal-Derived Magmas as a Result of Intra-Orogenic Extension-Related Intraplating. Ph.D. Thesis, University of Granada, Granada, Spain, 2015.

4. Cambeses, A.; Scarrow, J.H.; Montero, P.; Molina, J.F.; Moreno, J.A. SHRIMP U-Pb zircon dating of the Valencia del Ventoso plutonic complex, Ossa-Morena Zone, SW Iberia: Middle Carboniferous extension-related 'calc-alkaline' magmatism. Gondwana Res. 2015, 28, 735-756. [CrossRef]

5. Cambeses, A.; Montero, P.; Molina, J.F.; Hyppolito, T.; Bea, F. Constraints of mantle and crustal sources and interaction during orogenesis: A zircon SHRIMP U-Th-Pb and O isotope study of the 'calc-alkaline' Brovales pluton, Ossa-Morena Zone, Iberian Variscan Belt. Lithos 2019, 324-325, 661-683. [CrossRef]

6. Bea, F.; Montero, P.; Molina, J.F. Mafic precursors, peraluminous granitoids, and late lamprophyres in the Avila batholith: A model for the generation of Variscan batholiths in Iberia. J. Geol. 1999, 107, 399-419. [CrossRef]

7. Jerram, D.A.; Dobson, K.J.; Morgan, D.J.; Pankhurst, M.J. Chapter 8-The Petrogenesis of Magmatic Systems: Using Igneous Textures to Understand Magmatic Processes. In Volcanic and Igneous Plumbing Systems, 1st ed.; Burchardt, S., Ed.; Elsevier: Amsterdam, The Netherland, 2018; Volume 1, pp. 191-229.

8. Molina, J.F.; Montero, P.; Bea, F.; Scarrow, J.H. Anomalous xenocryst dispersion during tonalite-granodiorite crystal mush hybridization in the mid crust: Mineralogical and geochemical evidence from Variscan appinites (Avila Batholith, Central Iberia). Lithos 2012, 153, 224-242. [CrossRef]

9. Svetov, S.A.; Chazhengina, S.Y.; Stepanova, A.V. Geochemistry and Texture of Clinopyroxene Phenocrysts from Paleoproterozoic Picrobasalts, Karelian Craton, Fennoscandian Shield: Records of Magma Mixing Processes. Minerals 2020, 10, 434. [CrossRef]

10. Zandomeni, P.S.; Moreno, J.A.; Verdecchia, S.O.; Baldo, E.G.; Dahlquist, J.A.; Morales Cámera, M.M.; Balbis, C.; Benítez, M.; SerraVarela, S.; LemboWuest, C.I. Crystallization Conditions and Petrogenetic Characterization of Metaluminous to Peraluminous Calc-Alkaline Orogenic Granitoids from Mineralogical Systematics: The Case of the Cambrian Magmatism from the Sierra de Guasayán (Argentina). Minerals 2021, 11, 166. [CrossRef]

11. Casquet, C.; Galindo, C. Magmatismo varisco y postvarisco en la Zona de Ossa-Morena. In Geología de España, 1st ed.; Vera, J.A., Ed.; Sociedad Geológica de España-Instituto Geológico Minero España: Madrid, Spain, 2004; Volume 1, pp. $194-199$.

12. Casquet, C.; Galindo, C.; Tornos, F.; Velasco, F.; Canales, A. The Aguablanca Cu-Ni ore deposit (Extremadura, Spain), a case of synorogenic orthomagmaticmineralization: Age and isotope composition of magmas (Sr, Nd) and ore (S). Ore Geol. Rev. 2001, 18, 237-250. [CrossRef]

13. Moita, P.; Santos, J.F.; Pereira, M.F. Layered granitoids: Interaction between continental crust recycling processes and mantlederived magmatism. Examples from the Évora Massif (Ossa-Morena Zone, Southwest Iberia, Portugal). Lithos 2009, 111, 125-141. [CrossRef]

14. Tornos, F.; Galindo, C.; Casquet, C.; Rodríguez Pevida, L.; Martínez, C.; Martínez, E.; Velasco, F.; Iriondo, A. The Aguablanca $\mathrm{Ni}-(\mathrm{Cu})$ sulfide deposit, SW Spain: Geologic and geochemical controls and the relationship with a midcrustal layered mafic complex. Miner Depos. 2006, 41, 737-769. [CrossRef]

15. Molina, J.F.; Moreno, J.A.; Castro, A.; Rodríguez, C.; Fershtater, G.B. Calcic amphibole thermobarometry in metamorphic and igneous rocks: New calibrations based on plagioclase/amphibole Al-Si partitioning and amphibole/liquid Mg partitioning. Lithos 2015, 232, 286-305. [CrossRef] 
16. Molina, J.F.; Cambeses, A.; Moreno, J.A.; Morales, I.; Montero, P.; Bea, F. A reassessment of the amphibole-plagioclase NaSi-CaAl exchange thermometer with applications to igneous rocks. Am. Mineral. 2021, in press. Available online: https://scholar.google. com/citations?hl=es\&user=Cl4OTgEAAAAJ\&view_op=list_works\&sortby=pubdate\# (accessed on 15 April 2021).

17. Mutch, E.J.F.; Blundy, J.D.; Tattitch, B.C.; Cooper, F.J.; Brooker, R.A. An experimental study of amphibole stability in low-pressure granitic magmas and a revised Al-in-hornblende geobarometer. Contrib. Mineral. Petrol. 2016, 171, 85. [CrossRef]

18. Cambeses, A.; Scarrow, J.H.; Montero, P.; Lázaro, C.; Bea, F. Palaeogeography and crustal evolution of the Ossa-Morena Zone, Southwest Iberia, and the North Gondwana margin during the Cambro-Ordovician: A review of isotopic evidence. Int. Geol. Rev. 2017, 59, 94-130. [CrossRef]

19. Ábalos, B.; Gil Ibarguchi, J.I.; Eguíluz, L. Cadomian subduction/collision and Variscan transpression in the Badajoz-Córdoba shear belt, Southwest Spain. Tectonophysics 1991, 199, 51-72. [CrossRef]

20. Apraiz, A.; Eguiluz, L. Hercynian tectono-thermal evolution associated with crustal extension and exhumation of the Lora del Río metamorphic core complex (Ossa-Morena zone, Iberian Massif, SW Spain). Int. J. Earth Sci. 2002, 91, 76-92. [CrossRef]

21. Azor, A.; Expósito, I.; González-Lodeiro, F.; Simancas, J.F.; Martínez-Poyatos, D. Propuesta de un modelo evolutivo para la Zona de Ossa Morena. In Geología de España, 1st ed.; Vera, J.A., Ed.; Sociedad Geológica de España-Instituto Geológico Minero España: Madrid, Spain, 2004; Volume 1, pp. 188-189.

22. Braid, J.A.; Murphy, J.B.; Quesada, C. Tectonic escape of a crustal fragment during the closure of the Rheic Ocean: U-Pb detrital zircon data from the late Palaeozoic Pulo do Lobo and South Portuguese zones, southern Iberia. J. Geol. Soc. Lond. 2011, 168, 383-392. [CrossRef]

23. Díaz-Azpiroz, M.; Castro, A.; Fernández, C.; López, S.; Fernández-Caliani, J.C.; Moreno-Ventas, I. The contact between the Ossa Morena and the South Portuguese zones. Characteristics and significance of the Aracena metamorphic belt, in its central sector between Aroche and Aracena (Huelva). J. Iber. Geol. 2004, 30, 23-51.

24. Díez-Fernández, R.; Arenas, R. The late Devonian Variscan suture of the Iberian Massif: A correlation of high-pressure belts in NW and SW Iberia. Tectonophysics 2015, 654, 96-100. [CrossRef]

25. Expósito, I.; Simancas, J.F.; González-Lodeiro, F.; Azor, A.; Martínez-Poyatos, D.J. Estructura de la mitad septentrional de la zona de Ossa-Morena: Deformación en el bloque inferior de un cabalgamiento cortical de evolución compleja. Rev. Soc. Geol. Esp. 2002, 15, 3-14.

26. Pereira, M.F.; Apraiz, A.; Silva, J.B.; Chichorro, M. Tectonothermal analysis of high temperature mylonitization in the CoimbraCórdoba shear zone (SW Iberian Massif, Ouguela tectonic unit, Portugal): Evidence of intra-continental transcurrent transport during the amalgamation of Pangea. Tectonophysics 2007, 461, 378-394. [CrossRef]

27. Pereira, M.F.; Chichorro, M.; Silva, J.B.; Ordóñez-Casado, B.; Lee, J.K.W.; Williams, I.S. Early Carboniferous wrenching, exhumation of high-grade metamorphic rocks and basin instability in SW Iberia: Constraints derived from structural geology and U-Pb and 40Ar-39Ar geochronology. Tectonophysics 2012, 558-559, 28-44.

28. Rosas, F.M.; Marques, F.O.; Ballèvre, M.; Tassinari, C. Geodynamic evolution of the SW Variscides: Orogenic collapse shown by new tectonometamorphic and isotopic data from western Ossa-Morena Zone, SW Iberia. Tectonics 2008, 27, TC002333. [CrossRef]

29. Simancas, J.F.; Carbonell, R.; González-Lodeiro, F.; Pérez-Estaún, A.; Juhlin, C.; Ayarza, P.; Kashubin, A.; Azor, A.; MartínezPoyatos, D.J.; Almodóvar, G.R.; et al. Crustal structure of the transpressional Variscan orogen of SW Iberia: SW Iberia deep seismic reflection profile (IBERSEIS). Tectonics 2003, 22, 1062. [CrossRef]

30. Simancas, J.F.; Carbonell, R.; González-Lodeiro, F.; Pérez-Estaún, A.; Juhlin, C.; Ayarza, P.; Kashubin, A.; Azor, A.; MartínezPoyatos, D.J.; Saez, R.; et al. Transpressional collision tectonics and mantle plume dynamics: The Variscides of southwestern Iberia. Geol. Soc. Lond. Mem. 2006, 32, 345-354. [CrossRef]

31. Chichorro, M.; Pereira, M.F.; Díaz-Azpíroz, M.; Williams, I.S.; Fernández, C.; Pin, C.; Silva, J.B. Cambrian ensialic rift-related magmatism in the Ossa-Morena zone (Évora-Aracena metamorphic belt, SW Iberian Massif): Sm-Nd isotopes and SHRIMP zircon U-Th-Pb geochronology. Tectonophysics 2008, 461, 91-113. [CrossRef]

32. Castro, A.; Fernández, C.; El-Hmidi, H.; El-Biad, M.; Díaz, M.; De la Rosa, J.; Stuart, F. Age constrains to the relationships between magmatism, metamorphism and tectonism in the Aracena metamorphic belt, southern Spain. Int. J. Earth Sci. 1999, 88, 26-37. [CrossRef]

33. Ordóñez-Casado, B. Geochronological studies of the Pre-Mesozoic basement of the Iberian Massif: The Ossa Morena zone and the Allochthonous' Complexes within the Central Iberian zone. Ph.D. Thesis, Swiss Federal Institute of Technology, Zurich, Switzerland, 1998.

34. Pereira, M.F.; Chichorro, M.; Williams, I.; Silva, J.B.; Fernandez, C.; Díaz-Azpíroz, M.; Apraiz, A.; Castro, A. Variscan intraorogenic extensional tectonics in the Ossa-Morena Zone (Évora-Aracena-Lora del Río metamorphic belt, SW Iberian Massif): SHRIMP zircon U-Th-Pb geochronology. Geol. Soc. Lond. Spec. Publ. 2009, 327, 215-237. [CrossRef]

35. Brown, D.; Zhang, X.; Palomeras, I.; Simancas, J.F.; Carbonell, R.; Juhlin, C.; Salisbury, M. Petrophysical analysis of a mid-crustal reflector in the IBERSEIS profile, SW Spain. Tectonophysics 2012, 550-553, 35-46. [CrossRef]

36. Carbonell, R.; Simancas, J.F.; Juhlin, C.; Pous, J.; Pérez-Estaún, A.; González-Lodeiro, F.; Muñoz, G.; Heise, W.; Ayarza, P. Geophysical evidence of a mantle derived intrusion in SW Iberia. Geophys. Res. Lett. 2004, 31, L11601. [CrossRef]

37. Palomeras, I.; Carbonell, R.; Atarza, P.; Fernández, M.; Simancas, J.F.; Martínez-Poyatos, D.J.; González-Lodeiro, F.; Pérez-Estaún, A. Geophysical model of the lithosphere across the Variscan Belt of SW-Iberia: Multidisciplinary assessment. Tectonophysics 2011, 508, 42-51. [CrossRef] 
38. Bea, F.; Montero, P.; González-Lodeiro, F.; Talavera, C.; Molina, J.F.; Scarrow, J.H.; Whitehouse, M.J.; Zinger, T.F. Zircon thermometry and $\mathrm{U}-\mathrm{Pb}$ ion microprobe dating of the gabbros and associated migmatites of the Variscan Toledo Anatectic complex, Central Iberia. J. Geol. Soc. Lond. 2006, 163, 847-855. [CrossRef]

39. Gabaldón, V. Geological Map of Iberia scale 1:1,000,000, 1st ed.; Instituto Geologico y Minero: Madrid, Spain, $2001 ;$ p. 1.

40. Expósito, I. Evolución estructural de la mitad septentrional de la Zona de Ossa-Morena y su relación con el límite Zona Ossa-Morena/Zona Centroibérica. Ph.D. Thesis, University of Granada, Granada, Spain, 2000.

41. Pons, J. Un Modele d'evolution de complexes plutoniques: Gabbros et granitöides de la Sierra Morena Occidentale. Ph.D. Thesis, University of Paul Salvatier, Touluse, France, 1982.

42. Ochsner, A. U-Pb geochronology of the Upper Proterozoic Lower Paleozoic geodynamic evolution in the Ossa-Morena Zone (SW Iberia): Constraints on the timing of the Cadomian Orogeny. Ph.D. Thesis, University of Zurich, Zurich, Switzerland, 1993.

43. García-Lobón, J.L.; Rey-Moral, C.; Ayala, C. Comprehensive petrophysics of rocks from the Monesterio Antiform (Ossa-Morena Zone, SW Spain). J. Appl. Geophys. 2006, 59, 190-204. [CrossRef]

44. Sarrionandia, F. Estudio petrológico del complejo plutónico de Valencia del Ventoso (Badajoz). Ph.D. Thesis, University of Pais Vasco, Bilbao, Spain, 2005.

45. Sarrionandia, F.; Carracedo, M. Geocronología Rb-Sr y Sm-Nd del complejo plutónico de Valencia del Ventoso (Badajoz). Geogaceta 2007, 41, 207-210.

46. Sarrionandia, F.; Carracedo, M.; Eguíluz, L.; Ábalos, B. Caracterización de los granitoides variscos de tipo I (ACG) de la Zona de Ossa-Morena (Macizo Hespérico): Unidad Ácida del Plutón de Valencia del Ventoso (Badajoz). Geogaceta 2011, 50, 43-46.

47. Spear, F.S.; Kimball, C. RECAMP-A FORTRAN IV program for estimating $\mathrm{Fe}^{3+}$ contents in amphiboles. Comput. Geosci. 1984, 10, 317-325. [CrossRef]

48. Dale, J.; Powell, R.; White, R.W.; Elmer, F.L.; Holland, T.J.B. A thermodynamic model for Ca-Na clinoamphiboles in Na 2 O-CaO$\mathrm{FeO}-\mathrm{MgO}-\mathrm{Al}_{2} \mathrm{O}_{3}-\mathrm{SiO}_{2}-\mathrm{H}_{2} \mathrm{O}-\mathrm{O}$ for petrological calculations. J. Metamorph. Geol. 2005, 23, 771-791. [CrossRef]

49. Leake, B.E.; Woolley, A.F.; Arps, C.E.S.; Birch, W.D.; Gilbert, M.C.; Grice, J.D.; Hawthore, F.C.; Kato, A.; Kisch, H.J.; Krivovichev, V.G.; et al. Nomenclature of amphiboles. Report of the Subcommittee on Amphiboles of the International Mineralogical Association Commission on the New Mineral Names. Can. Min. 1997, 9, 623-651.

50. Cambeses, A.; García-Casco, A.; Scarrow, J.H.; Montero, P.; Pérez-Valera, L.A.; Bea, F. Mineralogical evidence for lamproite magma mixing and storage at mantle depths: Socovos fault lamproites, SE Spain. Lithos 2016, 266-267, 182-201. [CrossRef]

51. Baum, C.F. Stata: The language of choice for time-series analysis? Stata J. 2005, 5, 46-63. [CrossRef]

52. Spear, F.S. An experimental study of hornblende stability and compositional variability in amphibolites. Am. J. Sci. 1981, 281, 697-734. [CrossRef]

53. Czamanske, G.K.; Ishihara, S.; Atkin, S.A. Chemistry of rock-forming minerals of the Cretaceous-Paleocene batholith in southwestern Japan and implications for magma genesis. J. Geophys. Res. 1981, 86, 10431-10469. [CrossRef]

54. Anderson, J.L.; Smith, D.R. The effects of temperature and $\mathrm{fO}_{2}$ on the Al-in-hornblende barometer. Am. Mineral. 1995, 80, 549-559. [CrossRef]

55. Czamanske, G.K.; Wones, D.R. Oxidation during magmatic differentiation, Finnmarka complex, Oslo area, Norway, 2, The mafic silicates. J. Petrol. 1973, 14, 349-380. [CrossRef]

56. Schmidt, M.W.; Thompson, A.B. Epidote in calc-alkaline magmas: An experimental study of stability, phase relationships, and the role of epidote in magmatic evolution. Am. Mineral. 1996, 81, 462-474. [CrossRef]

57. Bea, F.; Morales, I.; Molina, J.F.; Montero, P.; Cambeses, A. Zircon stability grids in crustal partial melts: Implications for zircon inheritance. Contrib. Mineral. Petrol. 2021, 176, 18. [CrossRef]

58. Gualda, G.A.R.; Ghiorso, M.S.; Lemons, R.V.; Carley, T.L. Rhyolite-MELTS: A modified calibration of MELTS optimized for silica-rich, fluid-bearing magmatic systems. J. Petrol. 2012, 53, 875-890. [CrossRef]

59. Hewitt, D.A.; Wones, D.R. Phase equilibria of the micas. Rev. Mineral. 1984, 13, 201-256.

60. Wones, D.R.; Gilbert, M.C. Amphiboles in the igneous environment. Rev. Mineral. 1982, 9B, 355-390. 